\title{
Ethnobotany and Collection of West African Okra [Abelmoschus caillei (A. Chev.) Stevels] Germplasm in Some Communities in Edo and Delta States, Southern Nigeria
}

\author{
MATTHEW CHIDOZIE OGWU*1,2, MOSES EDWIN OSAWARU ${ }^{1}$, RAYMOND OSAS \\ AIWANSOBA $^{1} \&$ ROSEMARY NOREDIA IROH $^{1}$ \\ ${ }^{1}$ Department of Plant Biology and Biotechnology, Faculty of Life Sciences, University of Benin, Benin \\ City, Nigeria; ${ }^{2}$ Center for International Education, Keimyung University, Daegu, South Korea
}

\begin{abstract}
West African Okra (WAO), [Abelmoschus caillei (A. Chev.) Stevels, Malvaceae] is a garden cultivar in traditional agricultural system in West Africa, which is its center of diversity. In this study, WAO germplasm collection missions were carried out in Koko, Agbor and Umunede communities in Delta state and Abudu, Ogan, Ologbo, Agenebode communities in Edo state. Through random sampling, informants were selected and administered open and close ended questionnaire in order to assess local knowledge of WAO. Three scheduled visits were carried out to each community. A total of 179 accessions of WAO were collected from the different communities with 70 (ten from each community) accessions examined. Demographic distribution suggests $78.6 \%$ and $21.4 \%$ female to male respondents respectively. Majority of these germplasm holders practice Christianity $(88.1 \%)$ with the largest age range group encountered been 51-60 (29.4\%) while the least was 21$30(9.1 \%)$. The prominent occupation of respondents was farming $(45.2 \%)$ while dominant ethnic groups were Benin $(42.9 \%)$ and Ika (16.7\%). The presences of some vegetables considered as competitive substitute were recorded from the study area including Common Okra (Abelmoschus esculentus), Pumpkin (Telfairia occidentalis), Pigweed (Amaranthus sp.), Tomato (Lycopersicon esculentum), Bitter leaf (Vernonia amygdalina), Water leaf (Talinum triangulare) and Scent leaf (Ocimum gratissimum). Food and non-food use was recorded for WAO. Local names for the crop include Omonukpogbe, Onanukporu, Ukhia noka, Okuru okoki and Manukpogbe. Food use dominates non-food use for WAO in the study area regardless of the industrial potentials of the wood and phytochemicals. The study has emphasized the roles of traditional agriculture system and local knowledge in the management of crop germplasm.
\end{abstract}

Keywords: Ethnobotany, germplasm collection, traditional agriculture, vegetable, West African Okra (Abelmoschus caillei)

\section{INTRODUCTION}

West African Okra (WAO, Abelmoschus caillei (A. Chev.) Stevels, Malvaceae) is a garden-cultivar in traditional agricultural system, which is cultivated for its leaves, fruits, seeds, floral parts and stems (Osawaru \& Ogwu, 2013; Osawaru et al., 2014). It is found in all Nigerian states, more common in the South where it shares third and fourth place with tomatoes after Capsicum and Amaranthus among essential vegetables (Akoroda, 1986). The existence of WAO was pointed out by Stevels (1988). Studies by Charrier (1984), Siemonsma (1982), Stevels (1988) and Hamon et al. (1991) points directly to West Africa as the center of diversity of this crop plant (Figure 1). The seeds have been used as a substitute for

*Corresponding author: matthew.ogwu@uniben.edu coffee as a result of coffee beans shortage, an incident which promulgated the word Okra fever (Vipul, 2012).

WAO is a multipurpose crop because of its wide range of uses, which includes as human and animal feed, medicinal roles in orthodox and unorthodox practices, nutritional and health care functions and industrial applications (Adeniji et al., 2007; Dong \& Liang, 2007; Idu, 2006; Osawaru \& Dania-Ogbe, 2010; Ogwu \& Osawaru, 2014; Osawaru \& Ogwu, 2014; Obire, 2001; Siemonsma \& Hamon, 2002). In African languages, WAO is sometimes referred to as late or dry-season okra. Although crop duration shows enormous variation depending on cultivar, locality and season, and varies from four months to well over 12 months for maturity to occur. 


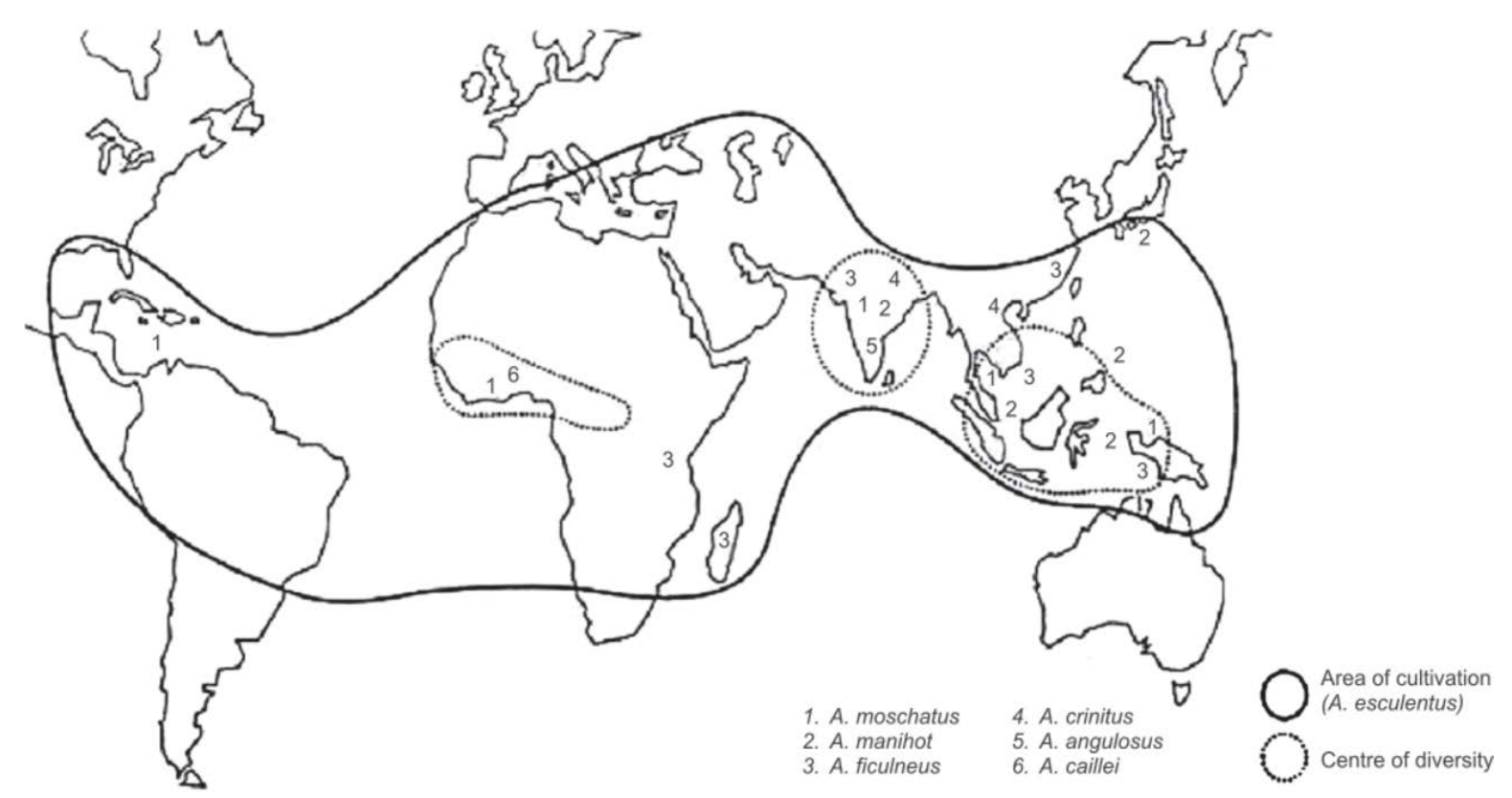

Figure 1. Geographical distribution of Abelmoschus species (Source: Charrier, 1984).

The views of most germplasm collectors relates to exploiting the area of exploration using a tool (knowledge of the people) in the management of their plant diversity (Igbokwe, 1999; Kolawole, 2002; Penny, 2001; Obire, 2002; Olaniyan, 2002; Osawaru \& DaniaOgbe, 2010; Usunalele, 2000). The ethnobotanical knowledge, genetic diversity and relationships among WAO germplasm may play an important role in breeding programmes. The value of germplasm collected depends on both the number of accessions and the diversity present (Ren et al., 2005). This is why collection, evaluation and storage of germplasm is vital to conservation strategy. Some of the reasons for collecting germplasm of a particular species from a particular area according to Painting (1996) include: rescue collecting, required for immediate use, gap filling, research purposes and for opportunistic reasons. In Nigeria, WAO is cultivated in traditional agriculture especially by women and serves as a source of income and employment (Ariyo, 1993); but the introduction of exotic varieties of the common Okra (A. esculentus) has led to a much reduced production of WAO as genetic enhancement have not been made for it (Schippers, 2000). This fact coupled with the vulnerability of areas of its diversity and distribution specifically Central and West Africa, give rise to the need for collection and storage of the germplasm of this crop. Different authors, which include Omohinmin and Osawaru (2005), Osawaru and Dania-Ogbe (2010) and Udengwu (2013) have reported the availability of this crop in different parts of Nigeria. According to Charrier (1984), the six main collecting sites are farmer's field, home gardens, markets, wild and weed, Institutes and farm/seed store.

Allem (2000), defined ethnobotany as the biological, economic, cultural inter-relationship studies between people and plants in the environment which they exist. It is the study of how people use plants (Jain, 2005). Osawaru and Ogwu (2014) referred to it as the realm between human interactions with plants in their environment because it essentially documents the traditional knowledge base of crops. Ethnobotany relates the relationship between the people of a given community or society, the environment and the plant diversity in that community. It is an integral part of indigenous/local knowledge of a particular society. Thus different communities have their own knowledge of plants and their uses (Osawaru \& Dania-Ogbe, 2010). Indigenous 
knowledge is in situ, unique, intimate with the people, valued and relevant, it is learnt over centuries and so it is preserved, transferred, adapted or adopted and a subset of global knowledge, thus it is an experience and wisdom of any community accumulated for creativity, conservation, management, food preparation, education and use of resources through customary ways in local (rural) communities (Pandey, 2004; Warren, 1990).

Green et al. (1999) stated that indigenous knowledge can contribute to biodiversity conservation, germplasm collection, food security and sustainable development and that it is a community based system for developmental processes. Warren (1992) reported that indigenous knowledge and plant diversity are complementary phenomena essential to human development. Local farmers (especially women) who are excellent conservers of biodiversity are the main custodian of genetic diversity (Cunningham, 1994). These farmers know the types, uses, cultivation processes, parts used, the importance placed on these crops by the local people, adaptability and quality from generation to generation of their crops (Esquivel et al., 1990; Hammer \& Mbewe, 1994).

The aim of this study is to carry out proper documentation of indigenous knowledge of $A$. caillei in some communities in Edo and Delta States, to assess the diversity of the plant in these communities as well as to evaluate the mode, state and level of conservation.

\section{METHODOLOGY}

\section{Study area}

This comprises of Delta and Edo States, which lies between $5.05^{\circ} \mathrm{N}-6.15^{\circ} \mathrm{N}$ and $4.00^{\circ} \mathrm{E}-$ $6.55^{\circ} \mathrm{E}$ (Figure 2). It is characterized mainly by low land relief. Climatic condition is typically wet and dry season. Rainfall and humidity is high for most part of the year. The vegetation varies from the mangrove swamp, tropical rain forest and derived savannah. The area has an estimated population of 4,762,491 (Delta 2,590,491 and Edo - 2,172,000). The pressure on land for agricultural and non-agricultural purposes is high, though the main economic activity of the people is farming.

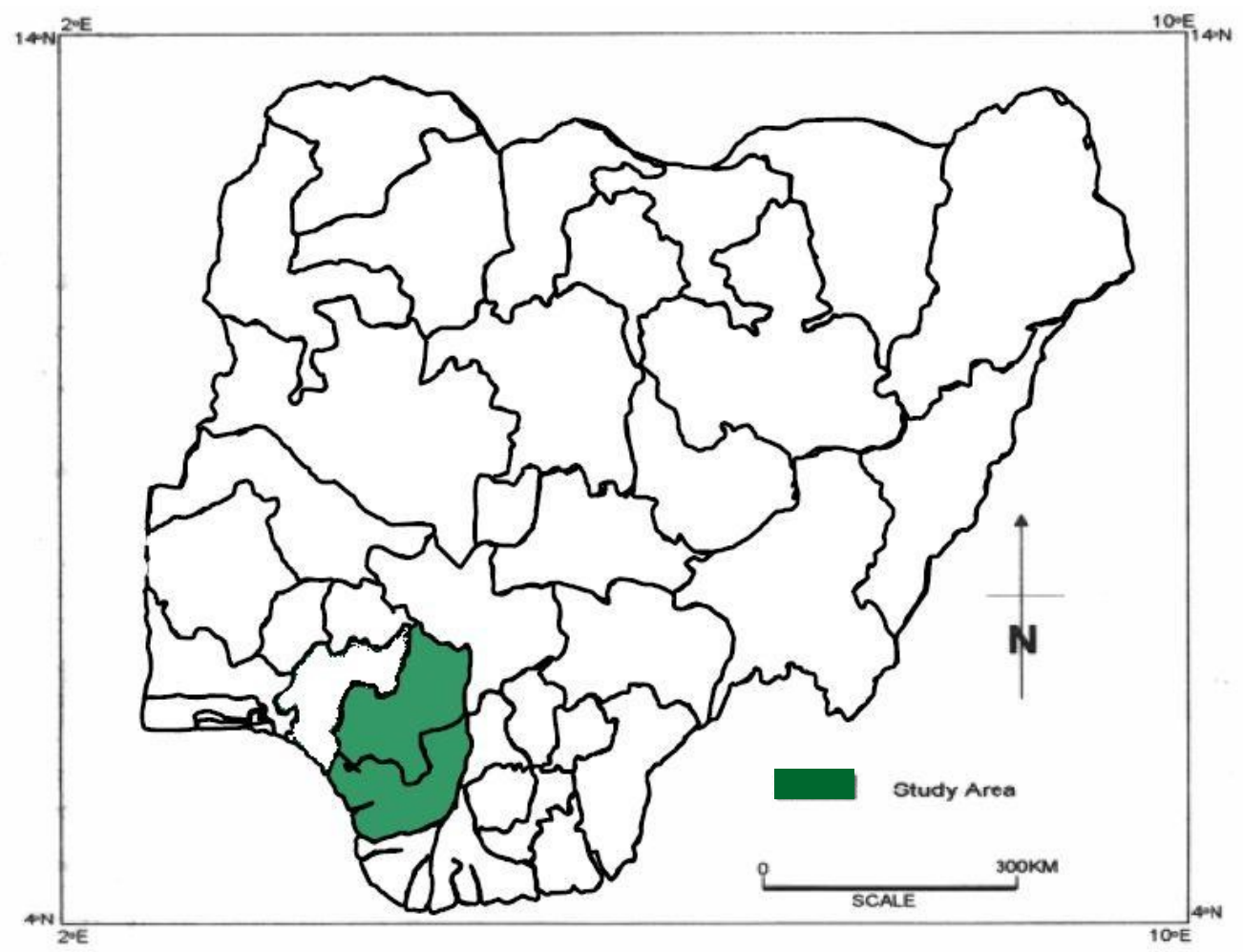

Figure 2. Map of Nigeria with study area (Edo and Delta states) (Source: Balogun, 2003). 


\section{Sampling frame}

WAO germplasm collecting missions was carried out in seven border communities located in both Delta and Edo States. The communities are Koko, Agbor and Umunede in Delta state and Abudu, Ogan, Ologbo, Agenebode in Edo state. Through random sampling informants were selected from each community comprising farmers, traders, home gardeners and even civil servants. The questionnaire administered was open ended and close ended one. Three visits were carried out to each community. Firstly, a visit was made to each community at different time when crop is on field (May to August) to select and enumerate key informants selected. This was followed by a second visit at the on-set of harvest period (October to January) to administer and retrieve questionnaires from enumerated key informants. Responses to the questionnaires were documented. Finally, guided walk was taken with key informants to collect the germplasm after permission was obtained from the community and germplasm holders. Identification of samples collected was based on procedures outlined by Mohammed (1991), Guarino (1995), Guarino \& Friis-Hassen (1995) and Osawaru \& Ogwu (2014). All collected germplasm are stored in the Plant Conservation Unit, University of Benin, Benin City, Nigeria.

\section{Data analysis}

Responses were documented and analyzed using descriptive statistics as outlined by Ogbeibu (2005).

\section{RESULTS}

Results are presented in Tables 1, 2, 3 and 4. A total of 179 accessions of WAO were collected from -the different communities (Table 1). The passport data of screened accessions of WAO are presented in Table 2.

The demographic distribution of respondents is presented in Table 3. A view of the distribution shows a $78.6 \%$ female to $21.4 \%$ male respondents. Christianity is the dominant religion with $88.1 \%$, Islam $(4.8 \%)$ and others $7.1 \%$. The largest age range group encountered is $51-60$ with $29.4 \%$ while the least group is 21 30 with $9.1 \%$. The most prominent occupation of respondents is farming (45.2\%), trading $(16.7 \%)$, and farming and trading (14.3\%), artisans and civil servants (11.9\% both). Benin $(42.9 \%)$ and Ika $(16.7 \%)$ were the dominant ethnic groups.

The local knowledge of respondents on WAO is presented in Table 4. Result shows that WAO is cultivated in the study area $(100 \%)$.

\section{Vegetable crops available and preference}

Other vegetable crops available in the study area in order of preference are Common Okra (Abelmoschus esculentus, Malvaceae), Pumpkin (Telfairia occidentalis, Curcubitaceae), Pigweed (Amaranthus sp., Amaranthaceae), Tomato (Lycopersicon esculentum, Solanaceae), Bitter leaf (Vernonia amygdalina, Asteraceae), Water leaf (Talinum triangulare, Portulacaceae), and Scent leaf (Ocimum gratissimum, Lamiaceae).

Table 1. West African Okra collected.

\begin{tabular}{lcccc}
\hline $\begin{array}{l}\text { Sample sites } \\
\text { (Community) }\end{array}$ & States & $\begin{array}{c}\text { No. of samples } \\
\text { collected }\end{array}$ & $\begin{array}{c}\text { No. of accessions } \\
\text { not examined }\end{array}$ & $\begin{array}{c}\text { No. of accessions } \\
\text { examined }\end{array}$ \\
\hline Abudu & Edo & 37 & 27 & 10 \\
Agbor & Delta & 17 & 7 & 10 \\
Agenebode & Edo & 40 & 30 & 10 \\
Ogan & Edo & 35 & 25 & 10 \\
Ologbo & Edo & 15 & 5 & 10 \\
Koko & Delta & 18 & 8 & 10 \\
Umunede & Delta & 17 & 7 & 10 \\
\hline Total & & $\mathbf{1 7 9}$ & $\mathbf{1 0 9}$ & $\mathbf{7 0}$ \\
\hline
\end{tabular}


Table 2. Passport of the screened accessions of West African Okra.

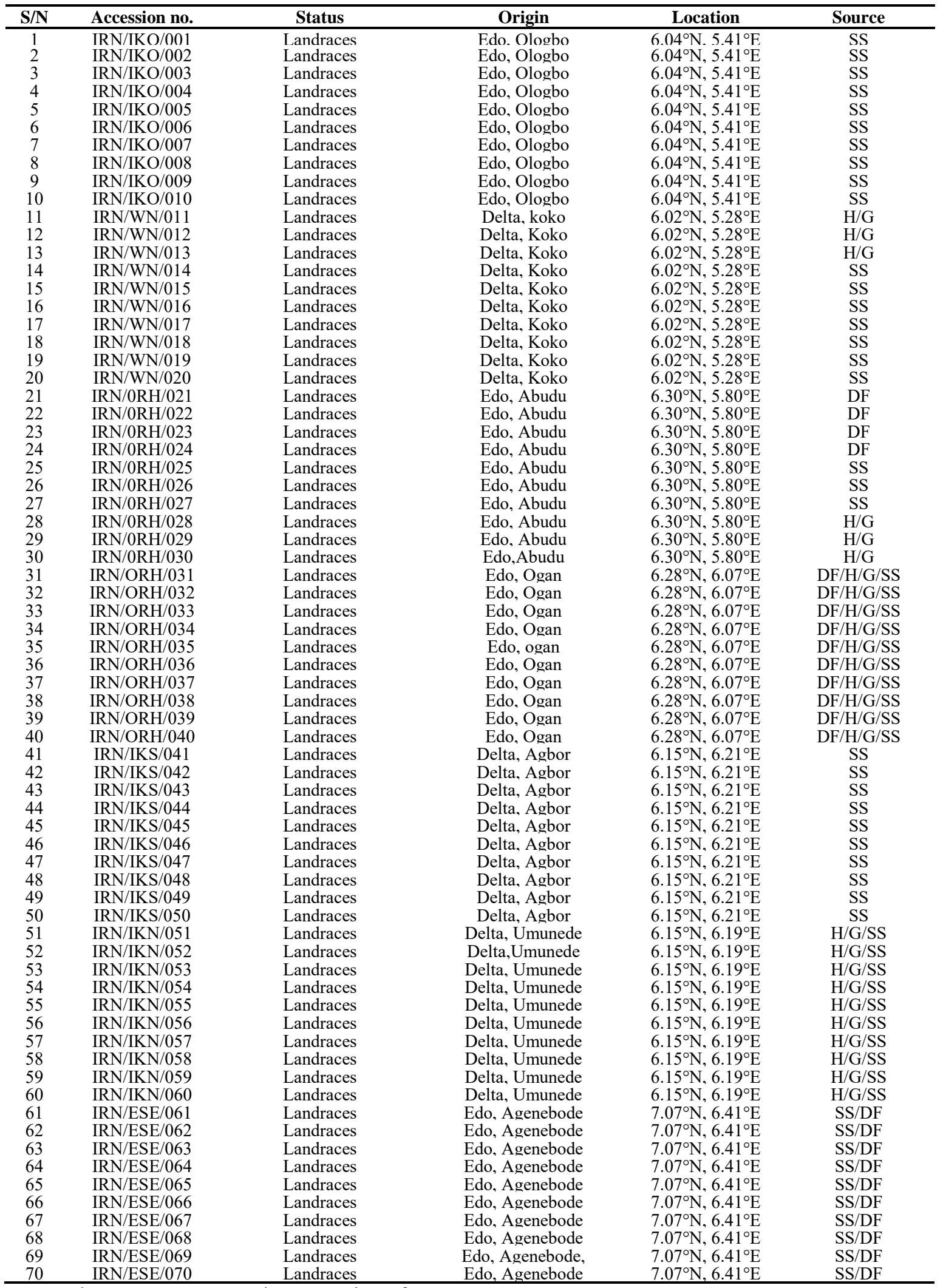

$\mathrm{SS}=$ Seed store, $\mathrm{HG}=$ Home garden, $\mathrm{DF}=$ Distant farm 
Table 3. Demographic characteristics of respondents.

\begin{tabular}{|c|c|c|}
\hline Characteristics & Frequency & Percentage (\%) \\
\hline \multicolumn{3}{|l|}{ Gender } \\
\hline Male & 75 & 21.40 \\
\hline Female & 275 & 78.60 \\
\hline \multicolumn{3}{|l|}{ Age Range } \\
\hline$<20$ & 0 & 0.00 \\
\hline $21-30$ & 32 & 9.14 \\
\hline $31-40$ & 45 & 12.83 \\
\hline $41-50$ & 95 & 27.14 \\
\hline $51-60$ & 103 & 29.43 \\
\hline $61-70$ & 39 & 11.14 \\
\hline $71-80$ & 36 & 10.29 \\
\hline \multicolumn{3}{|l|}{ Religion } \\
\hline Christian & 308 & 88.10 \\
\hline Muslim & 17 & 4.80 \\
\hline Other & 25 & 7.10 \\
\hline \multicolumn{3}{|l|}{ Occupation } \\
\hline Artisans & 42 & 11.90 \\
\hline Civil servant & 42 & 11.90 \\
\hline Farming & 158 & 45.20 \\
\hline Trading & 58 & 16.70 \\
\hline Farming and Trading & 50 & 14.30 \\
\hline \multicolumn{3}{|l|}{ Ethnic Groups } \\
\hline Bini & 150 & 42.90 \\
\hline Ishan & 33 & 9.50 \\
\hline Etsako & 33 & 9.50 \\
\hline Ika & 59 & 16.70 \\
\hline Isoko & 25 & 7.10 \\
\hline Ukwani & 33 & 9.50 \\
\hline Urhobo & 17 & 4.80 \\
\hline
\end{tabular}

\section{Sources of planting material}

Planting materials are sourced from previous harvest, markets and from friends and relatives.

\section{Storage of planting and harvested materials}

Respondents store the crop by tying the mature fruit on a rope above the cooking fire in the kitchen. Others remove the seeds from the pod, sun dry and then stored in tightly covered container. Respondents suggest that properly stored materials can remain viable from harvest to the next planting season.

\section{Who does the planting and when}

The farmers together with their family members do the planting. The planting period is between April and May.

\section{Uses}

The main use of the crop is as food mainly as an ingredient for making soup. According to respondents, the part used for making soup is the fruit and fresh succulent leaves. Various methods of preparation were reported. The young immature fruits can be sliced or grated, and beaten in its raw form or parboiled then beaten and then cooked for some minutes. Some of the respondents especially the Benins and Ikas add the grinded seeds of Irvingia sp. (Ogbono/African Bush Mango), to increase the viscosity of the soup. Others prepare it together with palm fruits (Elaies guineensis, Arecaceae) commonly known as "banga" The mature fruits are sliced, sundried and stored in air tight container. This is also used for making soup when the young fruits are no longer available. The young succulent leaves are also used as vegetables in soup. 
Nonfood use of the crop as recorded from respondents includes the use of the soft tip of the leaves to treat low sperm count in males. The mature leaves are used with other herbs to treat poisoning. The young okra fruits are eaten raw to clear coarse voice. For those who build huts in the farm, the dried stems are used as fire wood.

No wild type of the okra is known by the respondents, they only know the cultivated type, extent of cultivation ranges from low to very high. Majority of the tribes in the different communities have local names for the crop. For example, the Benins call it "Omonukpogbe", the Esans "Onanukporu", while Etsakos "Ukhia noka". Others are "Okuru okoki" for the Ikas and "Manukpogbe" for the Isokos and Urhobos.

\section{DISCUSSION}

The ethnobotany of West African Okra in some communities located in Edo and Delta states of Nigeria is documented in this study.
The study assessed traditional knowledge and socio-cultural practices associated with traditional agricultural systems, management and utilization of $A$. caillei. The knowledge of these practices will aid sustainable management, conservation, utilization and even pave way for further scientific studies on the crop in the world. According to Alonge and Alonge (2006), individual men and women in each generation adapt and add to knowledge and practices by adjustment to changing circumstances and environmental conditions. This is more pertinent in the light of current global climate change. The enormous diversity of WAO surveyed in this study along with the invaluable roles of traditional agriculture and local farmers is in line with the results of Osawaru and Ogwu (2013). Indigenous knowledge has been described as an important tool in documentation and conservation, classification and sampling of plant germplasm (Osawaru \& Dania-Ogbe, 2010). Berg et al. (1991) stated that behind any local variety or folk variety is knowledge.

Table 4. Degree of ethnobotanical response on West African Okra in the study area.

\begin{tabular}{lcc}
\hline Variable & Frequency & Percentage \\
\hline Status of collection & 350 & 100.00 \\
Cultivated & 0 & 0.00 \\
Wild & & \\
Frequency of the crop in the locality & 83 & 23.80 \\
Low & 200 & 57.10 \\
Medium & 50 & 14.30 \\
High & 17 & 4.80 \\
Very high & & \\
Extent of cultivation & 150 & 42.90 \\
Low & 125 & 35.70 \\
Medium & 50 & 14.30 \\
High & 25 & 7.10 \\
Very high & 300 & 85.70 \\
Method of propagation & 50 & 14.30 \\
Untilled land & 0 & 0.00 \\
Ridges & 0 & 0.00 \\
Mould & & \\
Dug ground & 58 & 16.70 \\
Importance in the locality & 125 & 35.70 \\
Cash & 167 & 47.60 \\
Subsistence & & \\
Both subsistence and cash & 325 & 92.90 \\
Utility (locally) & 25 & 7.10 \\
Food & & \\
Food/Non food use & 292 & 83.40 \\
Part(s) used & 0 & 0.00 \\
Fruits & 25 & 7.10 \\
Roots & 0 & 0.00 \\
Leaves/Fruits & 33 & 9.50 \\
Floral parts & &
\end{tabular}


Results suggest that the crop is cultivated in communities surveyed though fewer germplasm were observed in Ologbo, Agbor, Umunede and Koko (Table 1). This may be due to the presence of other vegetables considered as substitute in soup making. It is found in seed stores, home gardens and distant farms (Table 2). Indigenous knowledge about the crop is high in the study area. Allem (2000) and Sawadago (2005) reported that possessing knowledge of crop plants especially when associated with local names shows familiarity with the plants. As attributing names to plants establishes a kind of relationship between the people and plants and also tends to show and enhance their relationship with them.

Gender describes the social attributes of men and women and their roles. It can be assumed from the higher female percentage to that of male (Table 3), that females are more interested in the cultivation of the crop. It is an important tool for analyzing the roles of gender in crop cultivation. This supports the claim of Dania-Ogbe et al. (2001) that WAO is among women crops. Cunningham (1994) and Guarino (1995), reported that traditional farmers especially women are great custodian of knowledge about vegetable crops. Idu (2006) remarked that knowledge is first accessible to a member of a social group who are charged with specific resource management and production responsibility. The age of respondents reported in this study ranges from 21 - 80 years. Idu (2006) reported that age is an essential variable in determining the authenticity of knowledge in a given society and IIRR (1996) stated that knowledge is not restricted to a particular sex or age. Older persons have knowledge that differs from that of younger ones and younger persons might have knowledge better than older ones. The fairly wide age range used in this study has help in bringing together the older and younger persons knowledge about the crop in the study area. Osawaru and Ogwu (2013) opine that religious affiliation tend to affect local folklores and crop affinity. Falola et al. (1999) reported Christianity as an adopted religion. This means a deviation from the beliefs and cultural background of the ethnic groups. The implication of this is that modern varieties associated with the introduction of foreign religion are likely to replace local varieties. Guarino (1995) stated that farmers adopt new or modern varieties to replace local land races when these new varieties offer satisfaction to their household livelihood of which, belief, costume, moral laws, religion and socioeconomic factors play a major role. Having high proportion of peasant farmers that practiced traditional agriculture is of great importance as they provide man with crop species of economic importance, familiarity, maintaining and amplifying overtime their genetic variability (Bressan et al., 2005). Seven ethnic groups were encountered, the major ones being the Benins (42.9\%) and Ikas (16.7\%).

Food use dominate non-food use for WAO in the study area. Non-food uses include herb making to treat some ailments and the use of dried stems as firewood. Osawaru et al. (2014) suggest industrial use for the fibres of Abelmoschus species. The wood and phytochemicals present in WAO possess industrial potentials largely unexploited. Osawaru (2009) also reported the use of WAO in traditional medicine and its multipurpose nature for rope and sponge making. Parts used include fruits (83.4\%) and leaves/fruits (7.1\%). The traditional farmers who are custodian of plant genetic resources know how the crop is cultivated, parts used, how they are used, adaptability and quality of the crops and the importance placed on the crops by the local people (Alonge \& Alonge, 2006; Esquivel et al., 1990; Hammer \& Mbewe, 1994). Local traders also have knowledgeable information about uses, parts used and availability of plant products they sell. The use for non-food purposes of $A$. caillei includes information on nature, mythical beliefs and medicine. Osawaru and Dania-Ogbe (2010), reported that different communities in Southwestern Nigeria uses bloom of flowers of $A$. caillei as a seasonal indicator. The Igbos in the South Eastern part of Nigeria also consider the outgrowth of shoots from the base of the main stem of the crop as an indicator of the onset of raining season, while the Benins, Esans and Etsakos see the luxuriant growth of crop plant in intense dry season as an indication of fertile soil. The Benins, Igbos, Isokos, Urhobos and Itsekiris uses the crushed fruit or mucilage extract from any part of the crop plant for medicinal 
purposes such as child labour/bearing and as throat clearer and cleaner. Dead dried whole plant retted matured stem threshed fruit pods and old leaves are used for fuels, rope making, sponge making and for mythical belief respectively. Alcohol extract from leaves can eliminate oxygen free radicals, alleviate renal tabular-interstitial diseases, improve renal function and reduce proteinuria (Siesmonsma \& Hamon, 2002). It has been reported to prevent cancer and heart diseases (Idu, 2009). The mucilage has been implicated in midwifery and in trado-medicinal practices to ward off evil spirit (Obire, 2002).

The diverse ethnic groups give more understanding of the ethnobotany of the crop plant. This is evident in the local names assigned to the crop in the different locality. More so, these local names ascertain the identification of the crop by the different tribes (Osawaru, 2009). Penny (2001) reported that names and naming are important determinant factors in local societies, while Osawaru (2009) noted that names given to crop plants are associated with the economic peculiarity of the plant. Osawaru (2009) noted further that associated names of plants in different tribes refers to the life cycle, yield potentials, cultivar quality, etc. these local names aid detailed revelation about the crop. Though this documented indigenous knowledge recorded in this research is tribe dependent, it can be transferred to other communities that cultivate the crop.

In conclusion, the roles of local farmers and their system of cultivation is critical in germplasm collection, documentation and utilization. More so, they serve as custodians and manager of these resources which are important for the development and sustainable agriculture in the area of study.

\section{REFERENCES}

Adeniji, O.T., Kehinde, O.B., Ajala, M.O. \& Adebisi, M.A. (2007). Genetic studies on seed yield of West African okra [Abelmoschus caillei (A. Chev.) Stevels]. Journal of Tropical Agriculture, 45(1-2): $36-41$.
Akoroda, M.O. (1986). Relationships of plantable okra seed and edible fruit production. Journal of Horticultural Science, 61(2): 233-238.

Allem, A.C. (2000). Ethnobotanical testimony on the ancestors of cassava (Manihot esculenta Crantz. subsp. esculenta.). Plant Genetic Resources Newsletter, 123: 19-22.

Alonge, G.O. \& Alonge, A.O. (2006). Methods of data collection for research on indigenous knowledge. In F.C. Nworgu \& S. A. Olakojo (Eds.), Ethnoscience in agriculture for sustainable food production and livelihood. Bora agro ventures, Ibadan. Pp 94-99.

Ariyo, O.J. (1993). Genetic diversity in West African Okra [Abelmoschus caillei (A. Chev.) Stevels] - Multivariate analysis of morphological and agronomic characteristics. Genetic Resources and Crop Evolution, 40: 25-32.

Balogun, O. (2003). Senior secondary atlas. Longman, Nigeria.

Berg, T., Bjornstad, A., Fowler, C. \& Skroppa, T. (1991). Technology options and the gene struggle. Development and Environment No. 8 Occasional Papers Series C. As, Norway: NORAGRIC. Pp 72.

Bressan, E.A., Veasey, E.A., Peroni, N., Felipim, A.P. \& Pacheo dos Santos, K.M. (2005). Collecting yam (Discorea spp.) and sweet potato (Ipomea batatas) germplasm in traditional agriculture small holding in the Vale do Riberira, Salo Paulo, Brazil. Plant Genetic Resources Newsletter, 126: $1-11$.

Charrier, A. (1984). Genetic Resources. Abelmoschus (Okra). International Board for Plant Genetic Resources, (IBPGR) Rome, Italy. Pp 61.

Cunnigham, A.B. (1994). The role of ethnobotany and customary knowledge in the conservation and use of plant. In A. Putter (Ed.), Safeguarding the genetic basis of Africa `s traditional crops. Technical Centre for Agricultural and Rural Cooperation, the Netherlands/IPGRI/ Rome. Pp 147-155. 
Dania-Ogbe, F.M., Adebooye, O.C. \& Bamidele, J.F. (2001). Ethnobotany of indigenous food crops and useful plants; leafy vegetables of Southwest Nigeria; their identification, nutritional studies and cultivation of farmer assisted selected endangered species. Paper presented at the biennial meeting of the UNU/INRA College of Research Associates. 19-20 April, 2001, Accra, Ghana.

Dong, C.W. \& Liang, S.H. (2007). Function characteristic and comprehensive developing and utilization of Okra. Food Research and Development, 5: 58-67.

Esquivel, M.T., Shagarodsky, A. \& Hammer, K. (1990). Collecting plant genetic resources in Cuba; Report on the fourth mission. Kulturpflanza, 38: 345- 362.

Falola, T., Mahadi, A., Uhomoibhi, M. \& Anyanwu, U. (1999). History of Nigeria. Nigeria: Longman.

Green, E.C., Goodman, K.J. \& Hare, M. (1999). Ethnobotany, IPR and benefit sharing: the forest people's fund in Suriname. Indigenous Knowledge and Development Monitor, 14: 32-47.

Guarino, L. (1995). Secondary sources on culture and indigenous knowledge systems. In L. Guraino, V. Ramanatha-Rao \& R. Reid (Eds.), Collecting plant genetic diversity: technical guidelines. CAB, International, Wallingford. Pp 271- 298.

Guraino, L. \& Friis-Hassen, E. (1995). Collecting plant genetic resources and documenting associated indigenous knowledge in the field: a participatory approach. In L. Guraino, V. Ramanatha-Rao \& R. Reid (Eds.), Collecting plant genetic diversity: technical guidelines. $\mathrm{CAB}$, International, Wallingford. Pp 196-222.

Hammer, K. \& Mbewe, D.N. (1994). The role of traditional knowledge in germplasm collecting. In A. Putter (Ed.), Safeguarding the genetic basis of Africa's traditional crops. CTA, the Netherlands/IPGRI/Rome. Pp 147-155.
Hamon, S.A., Charrier, A. \& Koechin, J. (1991). Potential contributions to okra breeding through the study of their genetic resources. International Crop Network Series 5; Report on an International Workshop on Okra Genetic Resources. IBPGR, Rome. Pp 77-88.

Idu, M.E. (2006). The context of gender in indigenous knowledge and agricultural development. In F.C. Nworgu \& S.A. Olakojo (Eds.), Ethnoscience in Agriculture for Sustainable Food Production and Livelihood. Bora Agroventures Ibadan. Pp 100-111.

Igbokwe, E.M. (1999). From process to innovation: land use intensity practices among small holders rice farmers in Eastern Nigeria. Indigenous Knowledge and Development Monitor, 14: 7-11.

International Institute for Rural Reconstruction: IIRR (1998). Sustainable Agriculture Extension Manual. Nairobi. Pp 305.

Jain, S.K. (2005). Dynamism in ethnobotany. Ethnobotany, 17(122): 20-23.

Kolawole, O.D. (2002). Local knowledge utilization and sustainable rural development in the $21^{\text {st }}$ century. Indigenous Knowledge and Development Monitor, 19(3): 13-15.

Mohammed, T.I. (1991). Okra genetic resources in Sudan. IBPGR International Crop Network Series 5. USA. Indigenous Knowledge and Development Monitor, 9(1): 16-17.

Obire, L.O. (2002). Ethnobotanical survey of West African okra [A. caillei (A. Chev) Stevels] in Southern Edo State. B.Sc. Thesis. University of Benin, Benin City, Nigeria. Pp 37.

Ogbeibu, A.E. (2005). Biostatistics. Benin City: Mindex Publishing Company Limited.

Ogwu, M.C. \& Osawaru, M.E. (2014). Comparative study of microflora population on the phylloplane of common Okra [Abelmoschus esculentus Lin. (Moench.)]. Nigerian Journal of Biotechnology, 28: 1725. 
Olaniyan, A. (2002). Traditional methods of processing locust beans (Parkia clappertonisnner). Indigenous Knowledge and Development Monitor, 5: 3-4.

Omonhinmin, C.A. \& Osawaru, M.E. (2005). Morphological characterization of two species of Abelmoschus esculentus and A. caillei. Plant Genetic Resources Newsletter, 144: 51-55.

Osawaru M.E. \& Ogwu, M.C. (2014). Ethnobotany and germplasm collection of two genera of Cocoyam (Colocasia [Schott] and Xanthosoma [Schott], Araceae) in Edo State Nigeria. Science Technology and Arts Research Journal, 3(3): 23-28.

Osawaru, M.E. \& Dania-Ogbe, F.M. (2010). Ethnobotanical studies of West African okra, [Abelmoschus caillei (A. Chev) Stevels] from some tribes of south western Nigeria. Science World Journal, 5(1): 3642.

Osawaru, M.E. \& Ogwu, M.C. (2013). Collecting West African Okra [Abelmoschus caillei (A. Chev.) Stevel] germplasm from traditional agriculture in parts of southwestern Nigeria. The Bioscientist, 1(2): 171-181.

Osawaru, M.E. Ogwu, M.C. \& Emokpare, A.A. (2014). Preliminary assessment of the microanatomy of okra [Abelmoshcus (L.)] wood. Egyptian Academic Journal of Biological Science (Botany), 5(1): 39-54.

Osawaru, M.E. (2009). Ethnobotanical and taxonomic studies of West African Okra [Abelmoschus caillei (A. Chev.) Stevels] from some states in southwestern Nigeria. PhD. Thesis, University of Benin, Nigeria.

Painting, K. (1996). Introduction to collecting. In: L. Guraino, V. Ramanatha- Rao \& R. Reid (Eds.), Collecting plant genetic diversity: technical guidelines. $\mathrm{CAB}$, International, Wallingford. Pp 25.

Penny, R.A. (2001). Gender and indigenous knowledge experiences in Nigeria and the USA. Indigenous Knowledge and Development Monitor, 9(1):16-17.
Ren, J., McFerson, J., Kresovich, R.L.S. \& Lamboy, W.F. (1995). Identities and relationships among Chinese vegetable Brassicas as determined by random amplified polymorphic DNA markers. Journal of American Society and Horticultural Science, 120(3): 548-555.

Sawadogo. M.J., Duedraogo, M., BelemBalma, B., Dossou, I. \& Jarvis, D. (2005). Influence of ecosystem component on cultural practices affecting the in situ conservation of agricultural biodiversity. Plant Genetic Resources Newsletter, 141: 19-25.

Schippers, R.R. (2000). African indigenous vegetables: an overview of the cultivated species. Natural Resources Institute/ACPEU Technical Centre for Agricultural and Rural Cooperation, Chatham, United Kingdom. Pp 214.

Siemonsma, J.S. \& Hamon, S. (2002). [Abelmoschus caillei (A. Chev) Stevels] In L.P.A Oyen \& R.H.M. Lemmens (Eds.), Plant Resources of Tropical Africa. Precusor PROTA Programs Wageningen, The Netherlands. Pp 27-30.

Siemonsma, J.S. (1982). West African okra: morphological and cytogenetical indications for the existence of natural amphidiploid of Abelmoschus esculentus (L) Moench and A. manihot (L) Medikus. Euphytica, 31: 241-252.

Stevels, J.C.M. (1988). A new combination of Abelmoschus (Malvaceae) in West and Central Africa. Adasonia, 2: 137-144.

Stevels, J.C.M. (1990). An agro-botany study of traditional vegetables of Cameroon. Wageningen Agricultural University, The Netherland.

Udengwu, O.S. (1998). Photoperiodic response of early and late okra types Abelmoschus esculentus and application to accelerated gene transfer. Nigeria Journal of Botany, 11: 151-160.

Usunalele, J.O. (2000). Vegetative growth and fruiting pattern of okra (Abelmoschus) B.Sc. Thesis, University of Benin, Benin City. Nigeria. Pp 61. 
Vipul, A. (2012). Okra (ladyfinger-bhindi) and health its benefits. Suratiundhiyu Publication, India. Pp 6.
Warren, D.M. (1992). Indigenous knowledge, biodiversity conservation and development. Keynote address on international conference on conservation of biodiversity in Africa: Local initiatives and institutional roles. $30^{\text {th }}$ August to $3^{\text {rd }}$ September. Nairobi, Kenya. Pp 21. 